\title{
Huge iceberg ploughmarks and associated corrugation ridges on the northern Svalbard shelf
}

\author{
J. A. DOWDESWELL ${ }^{1} * \&$ K. A HOGAN ${ }^{1,2}$ \\ ${ }^{1}$ Scott Polar Research Institute, University of Cambridge, Cambridge CB2 IER, UK \\ ${ }^{2}$ Now at British Antarctic Survey, Natural Environmental Research Council, High Cross, Madingley Road,
}

Cambridge, CB3 OET, UK

*Corresponding author (e-mail:jd16@cam.ac.uk)

Linear to curvilinear depressions on high-latitude continental shelves have long been regarded as the signature of the ploughing action of iceberg keels impinging on the sedimentary sea-floor (e.g. Woodworth-Lynas et al. 1991). These depressions vary in dimensions and pattern with the size of calved icebergs and their drift tracks through the polar seas. Two different sizes of iceberg appear to have affected the continental shelf north of Svalbard, producing distinctive sets of ploughmarks (Dowdeswell et al. 2010).

\section{Description}

Large numbers of linear and curvilinear depressions are present on the sea floor of the northern Svalbard margin at water depths $<615 \mathrm{~m}$ (Fig. 1). The depressions are of two types. The first are large quasi-linear features up to $23 \mathrm{~km}$ long, $1 \mathrm{~km}$ wide and 80 $\mathrm{m}$ deep (Fig. 1a, d). These features are clustered within a fairly well-defined band of water depths (from 400 to $615 \mathrm{~m}$ over an area of about $800 \mathrm{~km}^{2}$ ), above and below which few are present. At first sight, many features appear linear, but detailed inspection shows that some are slightly curvilinear, whereas others are composed of several straight sections interspersed with directional shifts of sometimes just a few degrees. In addition, individual linear features often appear to form part of a coherent pattern, reminiscent of the teeth of a comb moving through a deforming medium. These linked sets of features are up to $5 \mathrm{~km}$ wide (Fig. 1a) with sharply defined lateral margins (Fig. 1d). The terminations at the ends of features can be open or closed, with those at the deeper-water end usually being open (Fig. 1a).

Within and at the edges of a number of these large depressions are sets of small sub-parallel ridges, orientated orthogonal to the larger ones (Fig. 1c). These small ridges are generally 1 to $2 \mathrm{~m}$ in amplitude and spaced about 90 to $160 \mathrm{~m}$ apart (Fig. 1e). They occur in sets, with tens of ridges forming a subtle but relatively uniform pattern within the larger depressions (Fig. 1c, e).

A second type of depression is smaller and highly irregular (Fig. 1b). Direction changes of $90^{\circ}$ or more are often observed in a chaotic pattern. Individual segment length is generally less than $1 \mathrm{~km}$, although several segments often appear to be continuations of one another. Feature width and depth is $<100 \mathrm{~m}$ and $<10 \mathrm{~m}$, respectively. On the northern Svalbard margin, these smaller and less regular depressions are found in shallower water, typically at $<400 \mathrm{~m}$ (Fig. 1a). Like their larger counterparts, these features appear erosive. As well as cross-cutting one another they also overprint some of the larger depressions, implying a younger relative age (Fig. 1b).

\section{Interpretation}

Both types of linear to curvilinear depression are interpreted as a result of seafloor ploughing by the keels of relatively deepkeeled icebergs. Similar submarine landforms have been observed down to at least $500 \mathrm{~m}$ on Arctic and Antarctic continental shelves (e.g. Barnes \& Lien 1988; Dowdeswell et al. 1993). The deepest ploughmarks on the northern Svalbard margin, at about $80 \mathrm{~m}$ below the general level of the sea-floor, are some of the largest ever observed (Fig. 1a, d); Kuijpers et al. (2007) have reported features of similar dimensions from the West Greenland margin.

Parallel sets of large ploughmarks are likely to have been formed by one of two processes: either by single huge icebergs with a deep, high-relief base that is rough at a kilometre scale; or by a set of individual deep-keeled icebergs that is trapped in an extensive and thick multi-year sea-ice floe which provides a uniform pattern of drift. The latter suggestion is physically possible; the melange of icebergs and multi-year shorefast sea ice, sometimes known as 'sikussak', which forms in some Greenland fjords has deep-keeled icebergs embedded within it (Reeh et al. 1999; Dowdeswell et al. 2000). There are, however, few direct modern analogues for the operation of this process in open-ocean settings.

The orientation of very large ploughmarks on the northern Svalbard margin is predominantly NE-SW (Fig. 1a). Likely sources for these huge icebergs are the Franz-Victoria and St. Anna ice streams that drained northward to the Arctic Ocean terminus of a past, probably Late Weichselian Eurasian Ice Sheet (Vogt et al. 1994; Dowdeswell et al. 2010). The icebergs drifted westward, perhaps trapped within multi-year sea ice to account for their uniform orientation. Given that the smaller, less regular ploughmarks cross-cut the larger ones, these were formed later, probably from smaller icebergs produced towards the end of deglaciation. No icebergs of this size are calved from Svalbard or Russian Arctic ice caps today (Dowdeswell 1989).

The sets of 1 to $2 \mathrm{~m}$-high sub-parallel ridges, located within some larger ploughmarks north of Svalbard (Fig. 1c), are inferred to be so-called corrugation ridges similar to those reported from the floor of Pine Island Bay in the Amundsen Sea sector of Antarctica (Jakobsson et al. 2011). The small Antarctic ridges were suggested to have been formed by the motion of large, lightly grounded icebergs linked to tidal cycling, although several other origins for these distinctive but subtle landforms have been considered (Jakobsson et al. 2011).

\section{References}

BARNES, P. W. \& LIEN, R. 1988. Icebergs rework shelf sediments to 500 m off Antarctica. Geology, 16, $1130-1133$.

DOWDESWELL, J. A. 1989. On the nature of Svalbard icebergs. Journal of Glaciology, 35, 224-234. 
DOWDESWELL, J. A., VILLINGER, H., WHITTINGTON, R. J. \& MARIENFELD, P. 1993. Iceberg scouring in Scoresby Sund and on the East Greenland continental shelf. Marine Geology, 111, 37-53.

DOWDESWELL, J. A., WHITTINGTON, R. J., JENNINGS, A. E., ANDREWS, J. T., MACKENSEN, A. \& MARIENFELD, P. 2000. An origin for laminated glacimarine sediments through sea-ice build-up and suppressed iceberg rafting. Sedimentology, 47, 557-576.

DOWDESWELL, J. A., JAKOBSSON, M. et al. 2010. High-resolution geophysical observations of the Yermak Plateau and northern Svalbard margin: implications for ice-sheet grounding and deep-keeled icebergs. Quaternary Science Reviews, 29, 3518-3531.

KUIJPERS, A., DALHOFF, F., BRANDT, M. P., HÜMBS, P., SCHOTT, T. \& ZOTOVA, A. 2007. Giant iceberg plow marks at more than 1 km water depth offshore West Greenland. Marine Geology, 246, 60-64.

JAKOBSSON, M., ANDERSON, J. B. et al. 2011. Geological record of ice shelf break-up and grounding line retreat, Pine Island Bay, West Antarctica. Geology, 39, 691-694.

REEH, N., MAYER, C., MILlER, H., THOMSEN, H. H. \& WEIDICK, A. 1999. Present and past climate control on fjord glaciations in Greenland: implications for IRD-deposition in the sea. Geophysical Research Letters, 26, 1039-1042.

VOGT, P. R., CRANE, K. \& SUNDVOR, E. 1994. Deep iceberg plowmarks on the Yermak Plateau: Sidescan and $3.5 \mathrm{kHz}$ evidence for thick calving ice fronts and a possible marine ice sheet in the Arctic Ocean. Geology, 22, 403-406.

WOODWORTH-LYNAS, C. M. T., JOSENHANS, H. W., BARRIE, J. V., LEWIS, C. F. M. \& PARROTT, D. R. 1991. The physical processes of seabed disturbance during iceberg grounding and scouring. Continental Shelf Research, 11, 939-951.

\section{Figure caption}

Fig.1. Multibeam bathymetry and cross-profiles of iceberg ploughmarks on the northern Svalbard continental margin. (a) Multibeam bathymetric image showing examples of small and large ploughmarks. Large ploughmarks are up to $23 \mathrm{~km}$ in length and $1 \mathrm{~km}$ wide (Dowdeswell et al. 2010). Acquisition system Kongsberg EM120. Frequency $12 \mathrm{kHz}$. Grid-cell size $30 \mathrm{~m}$. (b) Greyscale image of smaller iceberg ploughmarks on the northern Svalbard margin. (c) Detailed greyscale image showing small ridges overprinting large ploughmarks but orientated perpendicular to them. (d) $3.5 \mathrm{kHz}$ sub-bottom profile across the large ploughmarks; individual ploughmarks are up to $80 \mathrm{~m}$ deep. The 'abrupt' slopes on the western side of the ploughmarks are not artefacts; the steep sides of the ploughmarks were not well-imaged by the profiler as the acoustic signal was not returned to the receiver from steep slopes. VE x 23. Acquisition system Kongsberg TOPAS PS018 parametric sub-bottom profiler (secondary beam frequency $0.5-6 \mathrm{kHz}$ ). (e) Seafloor depth profile along a large ploughmark showing amplitudes and wavelengths of the small ridges. VE x 28. (f) Location of study area (red box; map from IBCAO v. 3.0). 
